\title{
Ihmisenä olemisen ehdot
}

\section{Pauliina Haasjoki: Himmeä sininen piste. Helsinki 2019: Poesia. Riikka Kaihovaara: Villi ihminen. Jyväskylä 2019: Atena.}

Ilmastonmuutos on viimeisten vuosien ja vuosikymmenien kuluessa noussut polttavaksi huolenaiheeksi. Tieteellinen näyttö elinympäristössämme tapahtuneista muutoksista ja niiden syistä ovat kiistattomia, ennusteet tulevasta kehityksestä ovat vakuuttavia ja tarvittavat toimenpiteet tuhon välttämiseksi ovat tiedossa, mutta silti sitovia sopimuksia tulevaisuuden pelastamiseksi on saatu odottaa kuin kuuluisaa Godot'ta. Ilmastonmuutoksessa tiivistyy niin monenlaisia jakolinjoja identiteettipolitiikasta taloudelliseen eriarvoisuuteen ja kansainväliseen politiikkaan, että näiden kurominen yhteen on osoittautumassa mahdottomaksi tehtäväksi.

Yhtenä syynä tälle tukalalle tilanteelle voi pitää sitä, että pragmaattisten valintojen ohella reagointi ilmastonmuutokseen edellyttää muutosta ihmiskäsityksessämme. On nimittäin selvää, että viime kädessä keskustelut ilmastonmuutoksesta ja vaatimukset toimia pahimpien katastrofien välttämiseksi edellyttävät ihmisen ja elinympäristömme välisen suhteen syvällistä kyseenalaistamista ja uudistamista. Huoli ilmastosta ja maapallon kestokyvyn rajallisuudesta pitää aina sisällään kysymyksen siitä, millä tavalla suhtaudumme luontoon elinympäristönämme, missä määrin elämänmuotomme tuhoaa maailmaa ja millä keinon voimme kääntää tämän suhteen elvyttävälle kannalle.

Esseeteoksensa Villi ihminen ja muita luontokappaleita (2019) johdannossa Riikka Kaihovaara kyseenalaistaa modernin ihmisen luontokäsityksen, jossa on jälkiä sekä 1700-luvun lopun ja 1800-luvun teollistumisesta että romantiikasta. Siinä missä teollistuminen ajoi ihmiset yhä suuremmissa määrin kaupunkeihin ja luonto miellettiin teknologisen ja taloudellisen hyödyntämisen kohteena, romantiikan ajan taiteilijat pakenivat kaupunkien raadollisuutta luonnon puhtauteen ja viattomuuteen. Luonto alettiin nähdä ihmisestä erillisenä sfäärinä, jota oli mahdollista käyttää hyväksi tai josta oli mahdollista etsiä tietä jumaluuteen.

Kokoelman esseitä yhdistää tämän modernin länsimaisen luontosuhteen kyseenalaistaminen. Kaihovaara korostaa, että rajanveto ihmisen ja luonnon välillä on aikansa elänyt ja toteaa oman ajattelunsa lähtevän siitä, että "ihminen kaikkine systeemeineen ja keksintöineen on osa luontoa". Silti ihmisen erottaa luonnosta kyky eettiseen ajatteluun ja oman toimintansa arvosteluun, mutta myös taipumus muiden lajien ja kokonaisten ekosysteemien muokkaamiseen. Kaihovaaran esseissä ero ihmisen ja luonnon välillä ei ole annettu vaan syntyy, kun ihminen "paaluttaa omaa paikkaansa villeydestä, kesyttää ja kesyyntyy". 
Käsitteellinen siirtymä luonnosta villiyteen kehystää kaikkia Villin ihmisen esseitä. Niissä rakentuva jännite syntyy "kesytetyn, ihmisestä lähtöisin olevan, ja villin luonnon välille". Lopulta kyse on modernin ihmisen ympäristöön kohdistamasta vallasta ja ennen kaikkea siitä luopumisen opettelusta: "Villiys on hallinnan ja kontrollin vastakohta. Villiys on vastuun luovuttamista itseä suuremmille voimille. Villiys on sen kokemista, että nämä voimat elävät myös minussa. Villiys on antautumista ja voimankäyttöä samanaikaisesti. Villiys on nöyryyttä" (23).

Kaihovaaran tärkein käsitteellinen työväline on villiintyminen (rewilding), jolla on alun perin tarkoitettu kasvi- ja eläinlajien palauttamista elinympäristöihin ja jopa kokonaisten elinympäristöjen elvyttämistä. Kirjailija ja ympäristöaktivisti Georges Monbiotin jalanjäljissä Kaihovaara kuitenkin ymmärtää villiintymisen metaforisemmin ihmisen harjoittaman kontrollin vähentämisenä ja luonnon omien prosessien sallimisena. Tässä merkityksessä villiintyminen istuu hyvin moneen kokoelman esseeseen, oli aiheena sitten kokemus luonnon julmuudesta ja välinpitämättömyydestä "Viidakon julmuudessa" tai esimerkiksi mätänevän materian herättämän inhon rinnastaminen ihmismielen torjumiin ajatuksiin "Pimeän mielen ekologiassa".

Pohdinta villin ja kesytetyn luonnon suhteesta ilmenee konkreettisella tavalla esimerkiksi esseessä "Kansallispuisto palaa". Esseessä Kaihovaara tarkastelee aluksi suhdettaan kansallispuistoihin, joiden opastetut reitit, pitkospuut ja tulipaikat - niin sanottu luontoinfra - ei tyydytä hänen tarvettaan päästä keskelle luontoa. Esseessä rakentuva katsaus ihmisen pitkään historiaan luonnon muokkaajana osoittaa, että ajatus koskemattomasta luonnosta on tarpeeksi pitkässä historiallisessa katsannossa aina fiktiota. Alkuperäistä villeyttä ei toisin sanoen ole olemassa, on vain villiintymistä, uskallusta jättää silleen.

Kokoelmansa lopussa Kaihovaara toteaa, että koska hän ei koe rakastavansa kieltä, hän ei esseistinä ole runoilija, tuskin kirjailijakaan. Ihanneolotilansa Kaihovaara löytää omien sanojensa mukaan kielen ulottumattomista, ajatuksettomasta tilasta. On totta, etteivät Villin ihmisen esseet säkenöi ilmaisullaan, mutta silti Kaihovaaran näkemyksellisyys vakuuttaa. Lähitulevaisuudessa sivistyksemme tulee suurella todennäköisyydellä kohtaamaan monia kokoelman esseissä esitettyjä kysymyksiä ja tekemään tiliä menneiden toimiensa vahingollisuuden kanssa.

Pauliina Haasjoen ensimmäisessä esseekokoelmassa Himmeä sininen piste (2019) on sen sijaan äänessä kokenut runoilija. Jos Kaihovaaran esseiden voi ajatella suuntautuvan villiintymisen kautta maailman jäsentämiseen uudella tavalla, niin Haasjoen esseistä hehkuu sinnikäs ihmettely maapalloamme ja sen erityislaatuisuutta kohtaan - vielä ainakin toistaiseksi Maa on ainoa planeetta, joka pitää yllä ihmisen olemassaoloa. Haasjoen näkökulmaa voi pitää kosmisena, mutta kokoelman esseet nivoutuvat henkilökohtaisella, konkreettisella ja intiimilläkin tavalla tapaamme kuvitella ihmisen sijaa maailmankaikkeudessa. 
Haasjoen teos rakentuu viidestä laajasta esseestä, joista ensimmäisessä hän pohtii avaruuden valloittamisen kuvastoa ja siihen liittyvää tunnetta ihmisen teknologisesta mahdista. Toinen essee kartoittaa erilaisia visioita maailmanlopusta ja kolmannessa Haasjoki tarkastelee erilaisia kuvitelmia avaruusolennoista, jotka ovat luonteeltaan välttämättäkin antropomorfisia. Esseessä "Muunlajiset" sama vieraannuttava katse kohdistetaan posthumanistisessa hengessä niihin toisten lajien edustajiin, joiden kanssa jaamme maapallon. Viimeisessä esseessä "Kellokoneisto" Haasjoki kirjoittaa ihmisen kyvystä muokata elinympäristöään ja siitä, kuinka tämä antaa maapallon tulevaisuuden kannalta syytä sekä optimismiin että pessimismiin. Huolimatta Himmeän sinisen pisteen maailmoja syleilevästä näkökulmasta, valinta paremman maailman puolesta tehdään aina uudelleen pienimpienkin vaihtoehtojen välillä.

Siinä missä Kaihovaara pyrkii esseissään tiukkaan ja asiapitoiseen tyyliin, Haasjoki kirjoittaa laveammin ja sävykkäämmin. Himmeän sinisen pisteen esseissä muistojen ja kokemusten tunnelmalliset kuvaukset yhdistyvät erilaisten kulttuuristen tekstien erittäin tarkkanäköiseen luentaan. Aineistonaan Haasjoki käyttää ensisijaisesti kirjallisuutta romaaneista kvanttimekaniikan yleisesityksiin, mutta tämän lisäksi hän ammentaa muun muassa elokuvista, niin vanhoista Neuvostoliittolaisista avaruuden valloitusta esittelevistä "dokumenteista" kuin verrattain uudesta scifistä. Haasjoen esseetyyli elää tästä monimuotoisuudesta ja siirtymien vaivattomuudesta, joka parhaimmillaan luo lukijan ja esseistin välille jutustelevan ja läheisen suhteen.

Etymologiansa mukaisesti esseetä pidetään kirjallisuudenlajina, jossa ajattelun keskeneräisyys on jätetty näkyville. Esseet ovat yrityksiä, jotka eivät edes esitä pyrkivänsä kiistattomaan totuuteen. Himmeän sinisen pisteen esseissä keskeneräisyys ja epävarmuus ovat tärkeässä asemassa. Tämä näkyy ennen kaikkea siinä, kuinka Haasjoki tunnustaa oman ymmärryksensä ja omien tulkintojensa haavoittuvuuden. On osoitus kypsyydestä, kun kirjoittaja uskaltaa Haasjoen lailla jättää lukijalle näkyviin oman epävarmuutensa toteamalla esimerkiksi, ettei tiedä miten omat oletukset pitävät paikkansa tai mille ne ovat sokeita. Nämä ovat teoksen kokonaisuudessa pieniä lauseita, mutta tuovat kirjoittajan lukijan vierelle ja kiteyttävät oivallisesti esseen tavoitteen pukea ajattelua sanoiksi siten, että ne avaavat uusia näkymiä, eivät rajoita niitä.

Kaihovaaran ja Haasjoen esseekokoelmat eivät välttämättä tuo lukijalleen uutta tietoa elinympäristömme haavoittuvuudesta. Tämän sijasta ne keskittyvät kyseenalaistamaan totutun aseman, jonka ihminen on kulttuurin myötä itselleen luonnon edessä varannut, ja tuomaan näkyviin uudenlaisia asentoja, joihin ihminen voi maailmassa asettua. Tähän tavoitteeseen essee on oivallinen väline: essee on renessanssin laji, joka syntyi arvioimaan uudelleen ihmisen ja maailman suhdetta. Montaignen aikana kyseenalaistettiin kirkon ja klassisen sivistyksen valta ihmiskäsityksen lähteenä, nyt vastassa ovat 
toisenlaiset rajat - huoli tulevaisuudesta, mikä pakottaa meidät miettimään uudelleen suhdettamme vakiintuneina pidettyihin totuuksiin talouskasvusta, fossiilikapitalismista tai paikastamme maailmankaikkeudesta. Nopea muutos ei varmasti ole, mutta lukemalla pääsee alkuun.

\section{Veli-Matti Pynttäri}

kirjoittaja on esseisiin erikoistunut kirjallisuudentutkija 